\title{
MALE LINGUISTIC PATTERNS ADOPTED BY ANA CRISTINA VERA
}

\section{PATRONES LINGÜÍSTICOS MASCULINOS ADOPTADOS POR ANA CRISTINA VERA}

RAÚl SEBASTIÁN RAMÍREZ BASANTES ${ }^{1}$

Recepción:06 de agosto de 2020

Aceptación: 15 de octubre de 2020 



\title{
MALE LINGUISTIC PATTERNS ADOPTED BY ANA CRISTINA VERA
}

\section{PATRONES LINGÜÍSTICOS MASCULINOS ADOPTADOS POR ANA CRISTINA VERA}

Raúl Sebastián Ramírez Basantes

Keywords: Linguistic patterns, gender, community of practice, stereotype, public sphere.

Palabras clave: Patrones lingüísticos, género, comunidad de práctica, estereotipo, ámbito público.

\begin{abstract}
Several communities have taken gender as a fundamental element in the establishment of linguistic patterns. This is the case of the masculine linguistic style, traditionally considered appropriate for correct development in the public sphere. Despite adapting to changes in the social world, the study of these patterns constitutes a starting point for a contextual analysis of gender linguistic characteristics. This article describes the linguistic varieties based on the socio-cultural context of Ana Vera's

communities of practice; a member of the feminist group Surkuna; an organization that watches over the well-being of women; and girls criminalized for having abortions. Their linguistic development is studied in defense of the non-criminalization of abortion due to rape, in a debate proposed by the newspaper "El Comercio", facing Carlos Arsenio, representative of pro-life groups. Ana uses male linguistic patterns in similar situations as Carlos, mainly, when she seeks to emphasize; provides data: and de-
\end{abstract}


fends her speaking time. However, the presence of linguistic patterns, related to collectivity and solidarity, is denoted when describing other women's reality, facing criminalization and rejection. This is an example of the interaction between gender language patterns in a public setting.

\section{RESUMEN}

Varias comunidades han tomado al género como elemento fundamental en el establecimiento de patrones lingüísticos. Es el caso del estilo lingüístico masculino, considerado tradicionalmente como apropiado para un correcto desenvolvimiento en la esfera pública. A pesar de adaptarse a los cambios del mundo social, el estudio de estos patrones constituye un punto de partida para el análisis contextual de las características lingüísticas de género. Este artículo describe las variedades lingüísticas en función del contexto sociocultural de las comunidades de práctica de Ana Vera, miembro del colectivo feminista Surkuna, el cual vela por el bienestar de mujeres y niñas criminali- zadas por abortar. Se estudia su desenvolvimiento lingüístico en defensa de la no criminalización del aborto por violación, en un debate propuesto por diario El Comercio frente a Carlos Arsenio, representante de grupos pro-vida. Ana utiliza patrones lingüísticos masculinos en situaciones similares a las de Carlos, principalmente cuando busca enfatizar, proporcionar datos y defender su tiempo de habla. Sin embargo, se denota la presencia de patrones lingüísticos relacionados con la colectividad y solidaridad al describir la realidad de otras mujeres frente a la criminalización y rechazo. Este ejemplo muestra la interacción entre patrones lingüísticos de género en un entorno público.

\section{INTRODUCTION}

Language is a set of possibilities that allows our identity to be represented in the world through social interaction. "They can be understood as formal mechanisms, but they are also a set of possibilities, conventions, and strategies that help us to represent the world, our own identity and that allow us to relate to the people around us" (Tusón, 2016). This interaction is based on contextual conditions such as sex, age, 
social origin, and profession. These factors produce a repetition of patterns that end up modeling a common linguistic behavior (Pizarro, 2015).

Historically, men and women have been separated into different communities of practice (Tusón, 2016), so that both would face different environments with specific demands. The characteristics that differentiate each community of practice have as consequence the formation of linguistic use tendencies in the form of patterns, sociolects, or different discursive styles: masculine and feminine (Tusón, 2016). The exposure of a specific kind of speech will create a pattern to follow in the participants;

"Evidence shows that a tight-knit network structure is an important mechanism of language maintenance. Men's speech in many speech communities is closer to the vernacular than women's, and we can see that it is the close-knit social networks to which men have traditionally belonged which serve to maintain vernacular speech norms. Women's speech, then, is closer to the standard not because women are deliberately aiming at Standard English but because the less tight-knit networks to which women belong are less efficient at enforcing vernacular norms" (Coates, 2013).
Parents establish the first communicational patterns to be followed in a private space. Then, social interaction, in public locations like schools, streets, and universities, reinforces the use of a new public linguistic style determined by their gender role (Gutierrez \& Lovón, 2019). "Learning to perform masculinity or femininity in our society means among other things learning to use gender-appropriate language" (Coates, 2013). In turn, Acuña establishes that gender roles and characteristics structure ideologies that are preserved over time and shared through education. It is in schools, where gender stereotypes, such as speaking time, assertiveness, or passivity in the speech are being reinforced (Acuña, 2015). "Women in contemporary American society, like children, have restricted rights to speak, and that interruptions are used both to exhibit and to accomplish socially sanctioned relations of dominance and submission" (West and Zimmerman cited by Coates, 2013). These roles are traditionally established according to the quality of the activity an individual is supposed to perform. as the individual interacts with others in different situations. Both genders are forced to represent a lexical role established by social norms (Pizarro, 2015). Robin Lakoff argues that. Traditionally, the female speech was defined by social stereotypes, which, in the future, would 
end up being reinforced; "Women are discriminated against linguistically by how they appear represented in the structure of languages (in the lexicon and the grammatical system), but also by how society expects them to speak and express themselves" (Lakoff quoted in Acuña, 2015). Traditionally, gender differences are naturalized in the community, justifying this type of linguistic gender ideologies (Acuña, 2015).

According to Coates, the public domain is dominated by a masculine tendency where masculine language patterns are established as a norm (Coates, 2013). Tusón explains that:

"The masculine style is the most valued as an appropriate style for public and formal communication situations, while the feminine style is appropriate for intimate, family, and informal situations. From this different valuation, therefore, stigmatization of the feminine style emerges when it is used in public or formal situations" (Tusón, 2016).

Acuña describes a list of differences in speech according to gender. Female linguistic patterns "are attributed an indirect communicative style, lacking in power and authority, affective or emotional, cooperative, oriented towards the creation of intimacy and strong bonds of solidarity with the interlocutor", while male linguistic patterns are characterized by being "direct, powerful, informative, competitive and focused on the reaffirmation of personal status within a group" (Acuña, 2015). By traditionally operating in the private sphere, the female discourse was not considered to have a public communicative competence, a perception that was traditionally reinforced by the stereotype's naturalization (Coates, 2013).

Tusón clarifies that "it is not about establishing a mechanical and deterministic relationship between sex and linguistic use, nor can an essentialist vision of the feminine be accepted" (Tusón, 2016). The static form of this idiomatic perception ignores internal differences or externalities that could influence these groups, based on stereotyped misconceptions of men and women, which will end up reinforcing them (Mills cited in Acuña, 2015). It is from this point that Acuña specifies that this type of study must be understood as "a contextual realization or deployment of characteristics that are associated with "femininity" and with "masculinity" in each society and culture" (Acuña, 2015). Authors such as Holmes (2006) support this type of research, since "they serve as a point of reference for the analysis of femininity and masculinity in discourse" (Holmes cited in Acuña, 2015). 
Contextual factors, within the community, generate exceptions to these trends. When studying the production of vernacular language in a South Carolina population, Coates describes that linguistic change occurs as a consequence of "changing structures in society and the new roles being taken on by women" (Coates, 2013). Acuña proposes that both women and men constantly challenge prevailing gender ideologies, despite social pressure and influence;

"People are active subjects in the creation of their gender identities, understood in this way as something that is produced, performed or displayed, largely through discourse, and not as something that is possessed as an inherent characteristic, which is what was assumed in the search for stable differences" (Mills cited in Acuña, 2015).

Apaza, cited by Gutierrez and Lovón (2019), explains that it is the perception of a community that defines the characteristics of male or female speech. If the community, in which an individual operates, requires different linguistic characteristics from those established by the norm, the person will adopt the necessary linguistic patterns into their vocabulary. The conditions inside the context, where women develop, have a direct influence on their linguistic patterns (Pizarro, 2015). An example can be observed when men use a subtle and communal style to communicate more effectively with a female client. Women will feel identified with the feminine linguistic patterns used by men, increasing in this way, and the possibilities of achieving the goal (Gutierrez et al. 2019). In her book, "Women, Men, and Language", Coates describes a series of studies that analyze the linguistic change of women, both in private and public ambits, following the premise: "Linguistic change occurs in the context of linguistic variation" (Coates, 2013). The incorporation of women into the workplace, since industrialization, modified the context in which they developed. Language fulfilled a utilitarian function. People, consciously or unconsciously, adapt their language to express an identity related to the requirements of the social and work context where they develop; "Women, like men, respond to local circumstances: they make linguistic choices in the context of particular speech communities" (Coates, 2013).

The search for women's social positioning and equality has led them in some cases to include masculine linguistic patterns into their language (Gutierrez et al. 2019). By studying the rude and distant linguistic style of policewomen, Osterman concludes that they "tried to 
adapt to the police system, dominated by traditional norms of male behavior" (Osterman, 2003). The masculinization of the feminine language, in this case, is considered a product of planned construction. where a woman uses: words, phrases, patterns, or linguistic styles typical of men to successfully develop in certain circumstances (Gutierrez et al. 2019).

Tusón emphasizes that linguistic patterns are not static and are directly susceptible to changes in the social world (Tusón, 2016). This process can only occur within the context of linguistic variation, which ends up reflecting and maintaining social variation (Coates, 2013). This situation is evident in communities of practice, where the assessment process is developed differently from the traditional one. Osterman's (2003) work with women, in two different institutions, shows us how the community of practice establishes the parameters of the female discursive style. Women, within police institutions, maintained a style characterized by being distant, impolite, and less collaborative than that of women in a feminist care center, where a supportive and cooperative communicative style was used (Osterman cited in Acuña, 2015).

Ana Vera belongs to the feminist collective Surkuna, a community that fights for "access for women and girls, victims and survivors of violence and unjustly criminalized for aborting to justice" (Surkuna, 2020). They provide legal defense and accompaniment to women that had suffered childbirth as well as gender violence, and who were legally judged because of abortion, so that "women and girls live free of violence and have autonomy on their bodies" (Surkuna, 2020). Ana Vera is also the voice for free abortion in the Ecuadorian Assembly.

\section{MATERIALS AND METHODS}

This paper will use a descriptive methodology to identify male and female linguistic patterns used by the participants of the debate: "¿Despenalizar el aborto por violación?" (Vera \& Larco, 2019). This took place in El Comercio locations on January 29, 2019. Ana Cristina Vera is in a debate discussing with the representative of pro-life groups, Carlos Arsenio Larco. This debate is moderated by Mariela Rosero, editor of the "Society" section from El Comercio newspaper.

This type of research identifies the properties and the characteristics of an object or phenomena by collecting information about the variables without 
analyzing the interaction between them. These studies are useful to define the dimensions of a phenomenon in a determined context (Hernández, 2014).

Male linguistic patterns, used by Ana Cristina Vera, are going to be identified from the transcription of fragments related to the presence of specific gen- der characteristics in the linguistic categories described by Amparo Tusón Valls in her publication: "Language: interaction and sexual difference" (2016): Morphosyntax, prosody, lexicon, thematic organization, conversational mechanics, non-verbal elements, Assessment.

\section{RESULTS}

\section{Morphosyntax}

\section{Ana Cristina Vera:}

- Use of first person singular and plural: (12:16) "Yo desde mi trabajo como abogada defensora de las mujeres" - (12:08) "En el Ecuador, a las mujeres nos violan todos los días".

- Inclusive speech: (14:18) "Creemos que si una mujer que ha sido víctima de violencia sexual decide contar con ese embarazo..."

- Declarative sentences: (12:44) "Seis de cada diez denuncias de violación son en contra de niños, niñas y adolescentes menores de catorce años".

- Direct sentences: (13:01) "Las víctimas de violación viven esto como una tortura cotidiana".

- Eco questions: (33:40) "Eso es tergiversar la verdad y tergiversar la propuesta concreta. ¿No?" - (34:19) "Porque también generó un vínculo ahí. ¿No?"

\section{Carlos Arsenio Larco:}

- Use of first and third person singular: (00:50) "Por lo tanto yo creo que para poder centrar las ideas en el debate, uno no tiene que irse a los extremos".

- Impersonal speech: (00:57) "Uno no tiene que irse a los extremos, sino manejar la información, las circunstancias que son comunes y usuales".

- Enunciative sentences: (1:03) "Lo común y usual es que... el embarazo por causa de una violación de esta naturaleza es bastante improbable".

- Use of direct sentences: (1:28) "Una persona violada va a los servicios de salud".

- Use of aggressive modifiers: (3:34) "El sistema educativo no ha hecho absolutamente nada por cambiar en los diez últimos, perdón la expresión, cacareados años" - (03:58) "La única vez en que yo estuve a punto de 
sacarle físicamente a patadas de mi oficina".

\section{Mariela Rosero:}

- Use of first person plural and second person singular: (7:19) "Ella no penalizaría a una mujer que decidiera abortar" - (11:52) "¿Cuál es tu punto de vista?"

- Inclusive speech: (26:30) "vamos viendo que el efecto que se da en el vientre se ve luego".

- Interrogative and exclamatory sentences: (26:31) "¿Qué va a pasar si un hijo sabe que tiene el material genético de un violador?"

- $\quad$ Eco questions: (26:17) "Vemos nuestros hijos cuando estamos durante la gestación en el embarazo ¿no?"

- $\quad$ No use of modalizers.

\section{Prosody}

\section{Ana Cristina Vera:}

Presence of descending endings with no vocal extensions or vocalizations. "Staccato" rhythm with few intonation modulations and voice changes.

\section{Carlos Arsenio Larco:}

Presence of descending endings with no vocal extensions or vocalizations. "Staccato" rhythm with few intonation modulations and voice changes.

\section{Mariela Rosero:}

A tendency to high tones with ascending endings. Empathic intonation, with the use of vocalizations, that denotes follow-up to the theme ("mhm")

\section{Lexicon}

\section{Ana Cristina Vera:}

- Vocabulary referring to the public sphere: (12:16) "Yo desde mi trabajo como abogada defensora de las mujeres, patrocinadora de las niñas violadas sé que estas estadísticas son absolutamente conservadoras".

- Words that designate nuances (answers with details): (12:34) "Nosotras estamos acostumbradas a la imagen de un violador lejano, que interviene en la calle oscura" (13:22) "Porque la violación es sistemática, es cotidiana, está dentro de la familia, está dentro del hogar".

- Use of augmentatives: (14:52) "Yo he llevado casos de niñas... justamente procesadas por un aborto en caso de violación. Yo considero ello absolutamente injusto" - (15:08) "Creemos también que la otra opción que ha mencionado el doctor Larco es absolutamente válida" - (33:40) "Eso es tergiversar la verdad y tergiversar la propuesta concreta ¿no? Y creo que eso es súper importante que se aclare". 


\section{Carlos Arsenio Larco:}

- Vocabulary referring to the public sphere: (3:48) "Yo soy una persona, vehemente sí, pero trato de ser una persona tranquila, particularmente en mis actos de trabajo".

- Use of augmentatives: (8:40) "Si agrega el hecho de la carga emocional y de culpabilidad que se va a sobreabundar por el hecho de un aborto, encima de la violación, simplemente usted tiene el doble de carga en toda la vida. Y esa carga es muy difícil de darla de baja".

- Words that establish generalities (responses in general): (9:08) "Probablemente en esa situación, lo correcto es desarrollar una serie de protocolos que en lo posible permitan ayudar a la mujer".

- Foul vocabulary: (3:34) "El sistema educativo no ha hecho absolutamente nada por cambiar en los diez últimos, perdón la expresión, cacareados años" - (03:58) "La única vez en que yo estuve a punto de sacarle físicamente a patadas de mi oficina".

\section{Mariela Rosero:}

- Vocabulary referring to the public sphere: (6:33) "María Mercedes Cuesta, que por años ha tenido el discurso del respeto a la vida desde la concepción, se pone de pie en una asamblea y cuenta que desde los seis años fue abusada sistemáticamente".

- No use of augmentatives or diminutives.

\section{Textual thematic organization}

\section{Ana Cristina Vera:}

- Summarize and reformulate themes: (33:41) "Eso es tergiversar la verdad y tergiversar la vida... tergiversar la propuesta concreta"

- Thematic treatment from the internal to the external: (13:05) "Al ser la violación cotidiana y sistemática, podemos decir que las tasas de embarazo producto de una violación son mucho más altas de las que se hubiera esperado".

- Assertive style with few thematic changes.

\section{Carlos Arsenio Larco:}

- Summarize and reformulate themes: (21:17) "Si respetamos la vida, no hay una amenaza ni a la vida de la madre, a la vida física de la madre, si no a su mejor desarrollo emocional y psíquico. No hay una amenaza de vida, es decir, no estamos en la categoría de sí lo mato porque me mata".

- Thematic treatment focused on the exterior with many thematic changes. Assertive style. 


\section{Mariela Rosero:}

- Summarize and reformulate themes: (6:48) "Cultura de la violencia, una vida de violencia que viven muchas niñas y adolescentes en sus casos".

- Thematic treatment from the internal to the external with few thematic changes. Assertive style.

\section{Conversational Mechanics}

\section{Ana Cristina Vera:}

- Overlaps and competitive interruptions:

(45:02) Carlos Arsenio Larco: "Hay que ser muy... (Overlap) cuidadoso en eso porque son vidas, tanto las que están en el vientre como la otra que tiene que prolongarse con el tiempo".

(45:10) Ana Cristina Vera: (Interruption) "Yo ahí quiero decir una cosa Mariela..."

- Effort on keeping the conversation going.

\section{Carlos Arsenio Larco:}

- Overlaps and collaborative interruptions:

(40:32) Ana Cristina Vera: "Nadie quiere un embarazo no deseado, ninguna mujer... (Overlap)".

(40:34) Carlos Arsenio Larco: (Interruption) "Anita... no quiero interrumpirlas si no abonar al debate..."

- Competitive interruptions:
(48:34) Mariela Rosero: "Y yo les agradezco... (Overlap)".

(48:37) Carlos Arsenio Larco: (Interruption) "Solamente treinta segundos. Lo que no quisiera..."

- Effort on keeping the conversation going.

\section{Mariela Rosero:}

- Overlaps and competitive interruptions:

(48:23) Ana Cristina Vera: "(Overlap)... Porque en medio de este debate donde justamente lo que queremos es buscar un mejor horizonte para nuestro país".

(48:34) Mariela Rosero: "Y yo les agradezco..."

- More "work" to keep the conversation going. (Interviewer)

\section{Non-verbal elements (Annexes)}

Ana Cristina Vera:

- Wide arm and hand gestures, legs crossed at the knees.

\section{Carlos Arsenio Larco:}

- Wide arm and hand gestures, legs crossed at the knees.

\section{Mariela Rosero:}

- Gestural movements of hands and arms performed close to the body, legs crossed at the knees. 


\section{Style Rating}

\section{Ana Cristina Vera:}

- Style of public and formal communication with an emphasis on the analysis of intimate situations.

\section{Carlos Arsenio Larco:}

- Style of public and formal communication.

\section{Mariela Rosero:}

- Style of public and formal communication.

\section{FINDINGS \\ MALE PATTERNS ADOPTED BY ANA CRISTINA VERA IN THE DEBATE}

\section{Morphosyntax}

- Use of first person singular and plural: (12:16) "Yo desde mi trabajo como abogada defensora de las mujeres" - (12:08) "En el Ecuador, a las mujeres nos violan todos los días".

- Declarative sentences: (12:44) "Seis de cada diez denuncias de violación son en contra de niños, niñas y adolescentes menores de catorce años".

- Direct sentences: (13:01) "Las víctimas de violación viven esto como una tortura cotidiana".

\section{Prosody}

- Presence of descending endings with no vocal extensions or vocalizations. "Staccato" rhythm with few intonation modulations and voice changes.

\section{Lexicon}

- Vocabulary referring to the public sphere: (12:16) "Yo desde mi trabajo como abogada defensora de las mujeres, patrocinadora de las niñas violadas sé que estas estadísticas son absolutamente conservadoras".

- Words that designate nuances (answers with details): (12:34) "Nosotras estamos acostumbradas a la imagen de un violador lejano, que interviene en la calle oscura" (13:22) "Porque la violación es sistemática, es cotidiana, está dentro de la familia, está dentro del hogar".

- Use of augmentatives: (14:52) "Yo he llevado casos de niñas... justamente procesadas por un aborto en caso de violación. Yo considero ello absolutamente injusto" - (15:08) "Creemos también que la otra opción que 
ha mencionado el doctor Larco es absolutamente válida" - (33:40) "Eso es tergiversar la verdad y tergiversar la propuesta concreta ¿no? Y creo que eso es súper importante que se aclare".

\section{Textual thematic organization}

- Summarize and reformulate themes: (33:41) "eso es tergiversar la verdad y tergiversar la vida, tergiversar la propuesta concreta".

- Assertive style with few thematic changes.

\section{Conversational Mechanics}

- Overlaps and competitive interruptions:
(45:02) Carlos Arsenio Larco: "Hay que ser muy... (Overlap) cuidadoso en eso porque son vidas, tanto las que están en el vientre como la otra que tiene que prolongarse con el tiempo".

(45:10) Ana Cristina Vera: (Interruption) "Yo ahí quiero decir una cosa Mariela..."

\section{Non-verbal elements}

- Wide arm and hand gestures, legs crossed at the knees.

\section{Style Rating}

- Style of public and formal communication with an emphasis on the analysis of intimate situations.

\section{LIMITATION}

The investigation is limited to the description of linguistic patterns, which are present in the participants, in the debate. The obtained material can help future researches focus on the study of the change of female linguistic patterns: in time, the interaction of male and female linguistic patterns, the role of male linguistic patterns in women, causes of the variety of female linguistic patterns, their influence in the inclusion of women in public roles, and more. It may be a starting point to analyze the reasons behind the use of determined linguistic patterns in specific situations. The feminist environment is another point that needs to be considered. A descriptive study related to the conditions inside the community of practice can be a way to explain the use of linguistic patterns beyond the stereotype, in public and private ambits. 


\section{CONCLUSION}

There is a large number of male linguistic patterns adopted by Ana Cristina Vera, due to the public sphere, where she develops, which is also interrelated with inclusion patterns of intimacy and empathy: characteristic of female linguistic tendencies, as a result of her interest in understanding the context, where women who had suffered violence, develop.

In the area of morphosyntax, Ana Vera has adopted an inclusive speech, with direct and declarative sentences in the first person singular, to place her role in the public field as a lawyer specialized in the defense of women who had suffered violence while using the first-person plural. To identify herself with the community of battered women, she is up for.

In the area of prosody, she uses a "Staccato" rhythm, with the presence of descending endings, which supports a straightforward style that lacks vocal extensions, vocalizations, modulations, or voice changes. The use of these masculine patterns, along with wide arm and hand gestures, increases the impact of the information she is giving in the debate, making her arguments stronger and more convincing.

Ana Vera uses vocabulary from the public sphere. She increases the in- fluence of specific topics by using augmentatives after a tense she considers important. It is pivotal to analyze how some augmentatives she uses like, "super importante", are in some cases less formal than the rest of the speech. The use of a lexicon, proper of a private ambit in a public debate, is the result of the interrelation between male and female linguistic patterns.

When analyzing the textual thematic organization, we can consider that Ana Vera doesn't summarize and reformulate themes as frequently as the other participants. She is direct and assertive in her speech, with a few thematic changes. Even though she uses the first-person plural to include herself in the battered women's speech, she allows herself to talk about the topic from an intimate perspective, too. This is another interrelation between male and female linguistic patterns.

As the debate progresses, the overlaps and interruptions are more frequent. In the case of Ana Vera, there is an overlapping and forward competitive interruption, after Carlos Arsenio Larco uses a collaborative interruption, to hoard the speaking time. This shows how Ana Vera uses a male conversational mechanic to make her speech time respected. 


\section{REFERENCES}

Acuña, A. V. (2015). El lenguaje y el lugar de la mujer: sociolingüística feminista y valoración social del habla femenina. Universidade de Vigo, $1-30$.

Coates, J. (2013). Women, Men and Language: A Sociolinguistic Account of Gender. New York: Routledge.

Gutierrez, A. F., \& Lovón, M. A. (2019). The masculinization of the feminine language in peruvian films and monologues. Boletín de la Academia Peruana de la Lengua, 129149.

Hernández, R. (2014). Metodología de la Investigación. México D.F: McGraw-Hill.

Osterman, A. C. (2003). Communities of practice at work: gender, facework and the power of habitus at an all-female police station and a feminist crisis interventions cen- tre in Brazil. Discourse \& Society, 473-505.

Pizarro, G. (2015). El léxico en mujeres y hombres: restricciones inconscientes o culturales. Revista de lenguas modernas, 219-234.

Surkuna. (02 de 10 de 2020). Centro de apoyo y protección de los derechos humanos Surkuna. Obtenido de https://surkuna.org/

Tusón, A. (2016). Language, interaction and sexual difference. Enunciación, 138-151.

Vera, A. C., \& Larco, C. A. (29 de enero de 2019). ¿Despenalizar el aborto por violación? (M. Rosero, Entrevistador) Obtenido de https:// www.facebook.com/watch/ live $/$ ? $=341920839870844$ \&external_log_id=baa343ce7df41adb92457a9c479932cb 